\title{
Four Styles of Strategy Development
}

\author{
P. J. Idenburg
}

\begin{abstract}
When considering the number of movements, schools and wars of position, the professional field of strategic management would appear to be maturing. Four views of the strategy development process can be distinguished: rational planning, planning as a guided learning process, planning on the basis of logical incrementalism and emergent strategy formation. All four of these views play a role: rationality, learning experience and spontaneity supplement one another.
\end{abstract}

Many years ago, I attended an official celcbration on the occasion of the anniversary of the French Revolution. One of the speakers was a leading historian who began his lecture with the question of whether the French Revolution really did take place. He concluded that our historical insight is obstructed because the French Revolution tends to be equated to the storming of the Bastille on 14 July 1789. Development processes are then simplified to become actual events which are useful as symbolic markers but the events prevent us understanding the underlying structures and trends. Besides the storming of the Bastille, one can also think in terms of Dday, the fall of the Berlin Wall or Europe on 1 January, 1993.

And so one may also wonder whether strategic management is linked to specific actual events, such as the approval of a plan, the opening of a new factory or the agreement to an acquisition, or rather by a process of strategy development. An citrepreneur would not describe such events as being part of the process of strategic management.

\section{The Foundations of Strategic Management}

Strategic management is an emerging field within the broad area of management studies. Igor Ansoff's book, Corporate Stategy was published twenty-five

P. J. Idenburg is Deputy Director-General of Industry in the Dutch Ministry of Economic Affairs and Professor of Strategic Management at Twente University. ycars ago. It was the first promincent treatise in the field which can be traced back to the activities of J. O. McKinsey in the 1930s. In the Strategic Management Journal and elsewhere in the literature, a life-and-death battle has been going on for some time now between Henry Mintzberg and Igor Ansoff on the foundations of strategic management.' Such wars of position have been fought out since time immemorial on other scientific ficlds or within companies. The ficld of strategic management secms to be maturing.

Key words in the discussion between Mintzberg and Ansoff are 'prescriptive' and 'descriptive'. Ansoff claims that strategic management must lead to specific guidelines for management activities, while Mintzberg claims that strategic managenent can only be described in hindsight as a pattern in these activities, which is not formed deliberately. However, there must always be a relationship between the activities of managers and their objectives. Even if a pattern has been established in the past, differences in interpretation may arise with regard to the history of the strategy.

These key words do not touch on the cssential issuc. Is a train timctable or a strect map prescriptive or descriptive? Just as in strategic management, these are tools for achicving an objective. Strategic management, the train timetable and the street map do not give a step-by-step description of how to get from A to B. The efficiency and effectiveness of the route is the determining factor, not the way it was created.

Another area for debate is whether we are dealing with continuous change versus discontinuous change. Is this a fundamental difference? Do managers assess the opportunities and threats in their cnvironment as being continuous or discontinuous? This distinction is only uscful where it applics to the company itself. If the survival of the company is at risk, then it is a case of sink or swim and it is too late for strategy development. 
Company strategy consists of a framework of rules, in the light of which management activitics can be assessed as being either useful or uscless. Each manager is inundated with information on new facts and changes which can affect his mental models of the present and future. However, the markers of strategic management are specific decisions about the use of scarce resources such as finance, pcople and time. These decisions are not considered in the light of everyday events but on the basis of patterns and structures. Strategic management is the constructive change of situations by organizations of peoplc. In that sense, there can be no valid comparison with the artists's struggle with his materials to produce pottery, as Mintzberg suggests. ${ }^{2}$ The future of our organizations is not inevitable. We can influence that future if we know which objectives we must pursue in order to achieve a desired position.

\section{The Process of Strategy Development}

This discussion about the fundamentals of strategic management touches on a number of issues in business research and management education. These are closely interwoven with the vision of the process of strategy development. This is not about the formal procedure of strategic planning but concerns the management of the strategy development processes in a wider sense.

Mintzberg suggests that there are at least ten schools of strategy development. His criticism is mainly aimed at one of these schools, the 'Design School', established at Harvard, which is one of the three 'prescriptive' schools.

There are two fundamental dimensions in strategy devclopment, goal orientation (what) and process orientation (how). Cast in matrix format, this results in four views of the strategy development process, (sec Figurc 1):

(1) rational planning,

(2) planning as a guided lcarning process,

(3) logical incrementalism,

(4) emergent strategy.

All four contain a grain of truth as reflections of the practical activities of strategic management. They are inter-rclated. We shall examine these four alternative views in more detail.

\section{Rational Planning}

Rational planning as a form of strategy development is concerned with the development and formulation of attainable objectives. A management team located in A studies the alternatives and selects the route to be taken to B. All kinds of creative techniques and intuition can be employed in selecting the goals (option devclopment). However, after this selection process, there are rational arguments and analytical considerations as the basis for explicitly formulated options or optimal solutions for defincd problems. These are reduced to manageable sub-problems which must lead to plans of action. The implementation of these plans of action is controlled through "management by objectives'. Measuring is knowing. The approach is conceptual and systematic: strategy $\rightarrow$ structure $\rightarrow$ systems, ctc

Models for rational planning are based on itcrative strategy development. The mission and basic objectives of the company are determined, after which a choice is made between alternative strategies. Implementation plans are made, based on an assessment of the opportunitics and threats in the external environment, strengths (competitive advantage, core competencies) and weaknesses in

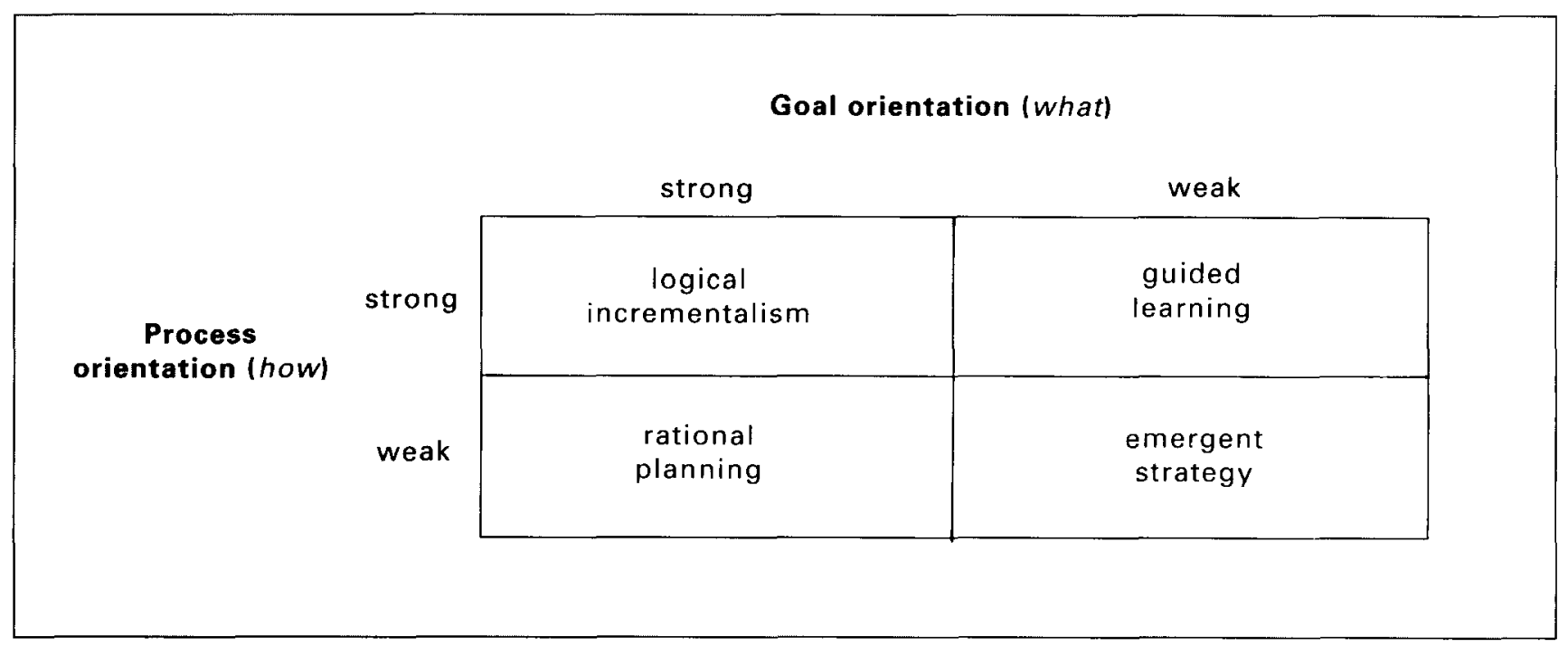

Figure 1. Four vicws on the process of stratcgy development 
the internal environment. Igor Ansoff worked out these analytical processes in great detail, though in later works he also paid attention to behavioural and political factors. Rational planning implies a deep involvement by top management in the formulation of strategies and action plans. This view of strategy development is founded on the assumption of a more or less predictable world in which the future position of the company can be determined in terms of quantifiable objectives. It is closely related to macro-economics, business economics and technical disciplines. Minds and hands are separate, plan formulation is distinct from implementation. Rational analysis outweighs beliefs, hope or intuition in strategy development. Day-to-day choices with regard to the investment of scarce resources, money, people and time, are made in relation to the pursuit of the stated objectives.

The Strategic Management authors who fit in with the rational planning view are Ansoff, Porter and other writers who Mintzberg classifies under the Design School. Of these authors, Michael Porter is best known through his presentation of concepts from industrial cconomics and business cconomics in a new form and in a practical manner. In his book Competitive Strategy, the emphasis is on his model of Industry Structurc. Competitive Advantage deals mainly with the model of the value chain with which the various activitics of a company can be distinguished in a stratcgic way. Techniques which are common here are the business portfolio analyses, such as the Industry Growth Rate-Relative MarketShare matrix with cashcows, dogs, question marks and stars of the Boston Consulting Group (1977) or the Industry Attractiveness-Competitive Position matrix of McKinsey \& Co. (1978), PIMS (Profit Impact of Market Strategy) and benchmarking, a methodology to determine profit potential or other targets of a company by comparison with sister companies or competitors. Most larger companies have formal planning processes which are based on this rational planning view.

The rational planning vicw assumes that people act in a structured and rational manner. This means that the approach is rather mechanical in character. But management will always require the human touch. Morcover, rationally analyzed problems can result in differing views as to their solutions. And vision, mental models, the implementation of plans, common values, etc., are difficult to pin down in analytical models. The processes of rational planning, i.c. how to get from $A$ to $B$, are often unclear and simplistic. However, this shortcoming is no justification for abandoning the rational planning train of thought. Rationality sometimes is under attack in our culture, and there is a risk that we will therefore produce plans which are based on insufficicnt analysis.

For a number of years the author has been a Managing Director of a leading international packaging group with operations in some 35 countrics and activitics in some 15 product groups (hereafter 'the IPG'). In 1987, a new Chief Executive initiated a long term planning process, which became known as the IPG-2000 project. In the initial 1987-1988 phase of this project, a detailed topdown analysis of the corporate portfolio resulted in the formulation of a number of quantified long term objectives for the Group:

is quantified profitability and growth targets;

t a quantified reduction of the so-called cost of non-quality with a resulting improvement in gross margin;

is no. 1 or 2 positions for all businesses in their respective markets;

is detailed targets for innovation and positions in growth markets.

\section{Planning as a Guided Learning Process}

In the experience of many companies, the mere formulation of strategic plans is an insufficient guarantec of bchavioural change by managers. Their mental models generally do not reflect the complexity of the world, as analyzed in or during the preparation of strategic plans. The guided learning-process approach to strategy development attempts to introduce these mental models of reality, so that they may be discussed. In this view on the process of strategy development, a common image of reality, a common language and the joint acquisition of new insights is just as important as the definition of exact goals for a desired future.

Scenarios, for example, are used not for their prescriptive quality or goal orientation but rather to influence consciousness, mental models and common language development ('encircle Caterpillar', 'rcalization of the upside potential', 'world class manufacturing'). In this view of strategy development, learning processes are not of a single loop nature-change, problem solving-but have double loop character, i.c. they lead to processes of continuous adaptation. This does not concern the extrinsic motivation, fed by SWOT analyses-determining strengths, weaknesses, opportunitics and threats as well as actions based thereon-but rather the development of creative tension. In a world which often turns out to be unpredictable, one must steer the situation from inner motivation and openness to change, because external goals cannot continuously determine the course to be taken.

Fvery good manager is creatively dissatisfied with the status quo. Strategy development is then a never ending process of continuous improvement. The orientation is en route from $\mathrm{A}$ to $\mathrm{B}$. On the way, the objective shifts and one comes to the conclusion that 
$B$ is really a new starting point and that one must plot a course from there to $\mathrm{C}$ or $\mathrm{D}$.

Authors on strategic management who primarily fit in the guided learning process vicw are C. Argyris, the Shell planners P. Wack and A. de Geus, Peter Schwartz, P. M. Senge and many other authors on the "lcarning organization'. 'The techniques used are scenarios, soft-systems methodology (a technique in which complex problems arc structured and systematic solutions are discussed in teamwork) and all kinds of 'innovative teamwork practices'. Companies which regularly employ these approaches are Royal Dutch/Shell, Procter \& Gamble, Ford, Apple and AT\&T, as reported in Peter Senge's book The Fifth Discipline.

The learning process approach recognizes that it is difficult or impossible to predict the future external and internal environment, and that organizations in a competitive situation in which the time factor is often important must learn quickly. Unstructured problems, uncertainties, dilemmas, paradoxes, cannot be satisfactorily solved with goal orientation alone. Learning in the nursery environment is abstract, true learning processes take place in practice with real problems and real persons. During thesc processes, we must regularly pause for reflection in order to learn from the present and the past. One can only detect the true potential of the company by actually pursuing stretched objectives. The criticism of the rational planning approach, that minds and hands are separated, actually applies equally to the guided learning-process approach because it is primarily concerned with the development of mental models rather than with action. The learning process view of strategy devclopment is closely linked to human resources management. Here, strategy development and management development go hand in hand.

The one-sided view of this approach is the creation of 'paralysis by analysis', characterized by a flat hierarchy, intelligent professionals, lots of information and ideas and being exclusively preoccupied with learning processes. However, these processes in companies require inspiration, a climate in which lerning is promoted but at the same time unequivocal steering, preserving the link between the process and the strategic objectives.

After the formulation of the corporate objectives in the years 1987-1988 the IPG changed the organizational structure of the Group by introducing a Group Council consisting of the Executive Board and the Managing Directors of the various Strategic Business Units. During two subsequent annual planning cycles the SBU's had to formulate their divisional plans in the light of the corporate objectives. A number of projects were carried out with the assistance of external consultants resulting in SBU targets for profitability, growth, acquisition and divestment. These projects resulted in the conclusion that the corporate objectives were not achievable for most SBU's and that the Group had to make a number of agonizing choices.

\section{Logical Incrementalism}

The vicw of logical incrementalism recognizes that the planned implementation of a strategy from $A$ to $\mathrm{Z}$ is an illusion. Every successful strategy devclopment process has clements of goal orientation and process orientation. The process develops in phases but each following phase builds on the previous phase and has its own internal logic: structure follows strategy, but organizational structure also impacts strategy development. Analysis and action are successive steps but ideas often manifest themselves in behaviour. On the way from $\mathrm{A}$ to $\mathrm{B}$, it becomes apparent that there are many routes to $\mathrm{B}$. Some are blocked off, others are dead ends, but we can take a number of steps in the right direction following each observation point.

Besides the stecring of process and goal orientation of the organization we must also recognize that the players within the organization have their own objectives and are experiencing their own learning processes. Power and political aspects of strategy devclopment and internal negotiation processes have a 'stepmother' image in business research and cducation. Strategic management touches on the essentials of present and future of organizations and is therefore not only a question of rationality but also of emotions, doubts, worries, intuition and stress.

Power politics may turn productive and constructive communication on common objectives into destructive processes on the basis of open or hidden personal agendas and mental models. It is not sufficiently recognized that implementation problems in strategic plans are not only the result of defective learning processes but also result from the fact that a policy is seldom neutral but always contains elements of power politics and internal negotiation (see Table 1).

The trendsetting author on logical incrementalism is James Brian Quinn. ${ }^{+}$Charles Handy and other authors on the study of organizations have also written about behavioural and power political processes in companies. Processes of logical incrementalism can often be detected in mergers and acquisitions (many integration issues become only relevant after the closing of the transaction; gradual realization of insufficient fit may lead to a step by step divestment decision) or when a top manager leaves the company (notice for example the dramatic shifts in direction taken by Gencral Motors after the departure of Robert Smith in 1992, British Airways after Lord King's step-down and the process of merger of Carnaud and Metal Box under the leadership of Jean Marie Descarpentrics and the 
Table 1. Policy and politics

\begin{tabular}{|c|c|}
\hline Policy & Politics \\
\hline * Structural analysis & *Analysis of influence \\
\hline${ }^{*}$ Competitors in the market place & " Competition in-house \\
\hline $\begin{array}{l}\text { * Open communication results in clear business } \\
\text { objectives }\end{array}$ & $\begin{array}{l}\text { * Individually dominated discussions result in responsibility } \\
\text { domains }\end{array}$ \\
\hline${ }^{*}$ Loyalty to objectives & ${ }^{*}$ Loyalty to individuals \\
\hline "Decisions based on shared insights & ${ }^{*}$ Decisions reached by lobbying \\
\hline${ }^{*}$ Decisions based on trade-offs in the business & $\begin{array}{l}\text { * Decisions based on trade-offs in the internal power } \\
\text { structure }\end{array}$ \\
\hline *Motivation: achievement of the corporation & * Motivation: promotion of the individual \\
\hline * Type of leadership 'statesman' & *Type of leadership: 'politician' \\
\hline
\end{tabular}

Source: J. P. Leemhuis, Shell.

subsequent opting out of the British sharcholders in the new group).

Logical incrementalism recognizes that the reality of strategic management comprises stecring goals as well as people. Incremental processes can be steered by leaders who recognize both their policy dimension and their political dimension.

Early in 1991 the Chief Executive of the IPG retired. Pending his retirement no choices had been made as to which SBU's and businesses would be maintained in the light of the stated corporate objectives or, alternatively, whether the corporate objectives had to be changed taking into consideration the SBU plans which, in a consolidated form, did not fit the original rational planning goals. When a new Chicf Executive was appointed, he quickly changed the political deadlock with regard to a number of personncl and business issues which had remained undecided for a number of years.

\section{Emergent Strategy}

In the fourth view of strategy development, that of emergent strategy, we miss both goal orientation and process orientation. According to this vicw, it is not possible to develop a perspective of the future and formulate explicit objectives in an unpredictable environment; instead, it is necessary to react in a flexible, opportunistic and accidental manner to new, unpredictable developments, and 'muddle through'.

According to Mintzberg, an important part of strategy development in companies consists of this flexible strategy, termed by him 'emergent strategy'. In this vicw companies are regularly overtaken by developments, react in an non-structured manner and learn by their mistakes. There are without doubt some examples of emergent strategy, for example General Electric's unplanned acquisition of mining interests before Jack Welch's Presidency and subsequent divestment, ICI's plans for splitting the company up under threat of Lord Hanson's assault, the spectacular demise of the British Motorcycle industry due to the Japanese motorcycle producers, as extensively reported by the Boston Consulting Group (1975) and Pascale (1984). However, the guided learning process view is based on the assumption that learning processes can be speeded up or improved upon.

Companics are regularly confronted with uncxpected events, which can sometimes also be seen as a break in a trend. Stratcgic objectives then have to be adjusted. If the route to $B$ is blocked, we must possibly return to A. Previous learning experiences may not be relevant to the new situation and the learning process cannot be guided if an immediate reaction is required. In that case, necessity knows no law, action drives the new reflection.

This view leaves the door wide open for all kinds of irrational mechanisms, wishful thinking, ignorance and conformism. The development is then motivated by external events which overshadow long term trends and structured changes. There are no techniques, tools or programmes at the manager's disposal. Vision becomes hallucination, the issue of business definition becomes: "What business are we in this year?'

In the course of 1991 the new Chicf Exccutive cmbarked on a major acquisition for the IPG which added some 30 per cent in size to the Group and a number of totally new businesses to the product portfolio. This acquisition was an opportunity which emerged but had certainly not been foreseen as an integral part of the IPG 2000 project. After this acquisition the IPG had to reconsider its prioritics and its corporate objectives. A new phase in the IPG 2000 project emerged in which a number of difficult decisions with regard to the future configuration of the business portfolio of the Group would have to be made.

\section{Shift of Emphasis}

Strategic management in large decentralized organizations comprises stecring strategy development processes at corporate and divisional level. Effective bchaviour in such organizations can only result from a rational attitude towards goals and processes. 
This does not exclude flexible reactions, although solid learning experience certainly facilitates this process. However, structures and codes are required in order to enable action in an uncertain world without being paralysed by great doubts.

This is probably different in smaller companies, where investment decisions with respect to finance, people and time are dominated by one or two persons. The vicw of strategy development as retrospective sensemaking would not seem to be realistic for larger organizations, who can only achieve success if the sum of the individual efforts results in added value. Orientation towards the future is reinforced by learning from the past. However, strategic action must be functional in relation to the future, even though later events may put this action in a different perspective. Strategy development is the management of goals, processes and power politics and will occasionally have to make way for emergent strategy when orientation towards goals or steered processes offers no solace.

All four visions of the strategy development process contain a grain of truth, as exemplified in the various phases of the IPG-2000 project. The emphasis in the process will shift over the course of time, depending on the cxtcrnal and intcrnal necessity on the one hand and the insight and preference of the managers of the strategy process on the other.

\section{Research and Education}

Managers are confronted almost daily with important issues in the fields of technology, organization and human resources. Only a few of them extract knowledge from university textbooks on strategic management or the results of academic business research. Many of them are the slave of some managerial model, usually courtesy of a consulting firm. 'However, those managers are the customers, business research the supplier. The results of strategic management research should provide answers to the issues with which managers wrestle. The final criteria must be whether the management activity is encouraged, supported or improved by the results of the research.

A great deal of academic research is based on the formation of theories (for example transaction-costs theory, agency theory, value-creation theories) and tests these theories without relating them to practical business issues. Research which only attempts to develop or test theoretical concepts has little chance of success. It is the task of the professional ficld of strategic management to either arrive at a synthesis or translation of the theory which can be applied to practical situations or, conversely, to translate practical issucs into theoretical models.

\section{Conclusion}

The four alternative views of the process of strategy development must be reflected in business research and education. One-sided presentation of goal oriented techniques and models is insufficient. Analytical intelligence is not the only strength required for managers and corporate planners, and which universitics must inculcate in their students. Case studics and practice-based tasks must help to increase understanding of organizational learning processes and the political dimension of strategy development.

In education, more attention must be paid to those techniques and models which provide understanding of the aspects of organizational change processes in order to increase the inter-personal and organizational skills of graduates. All too often, students mercly acquire cognitive knowledge, while cducation and training in the development of personal and process skills is too limited. Such skills arc a prerequisite for the success of strategy development.

\section{References}

(1) Strategic Management Journal, 11, 171-195 (1990); and 12. 449-466 (1991). See also: Mintzberg on The Rise and Fall of Strategic Planning, Long Range Planning, 25. 99-104 (1992).

(2) H. Mintzberg, Crafting strategy, Harvard Business Review, July-August, 66-75 (1987).

(3) A. de Geus, Planning as learning, Harvard Business Review 70-74 (1988); Peter Schwartz, The Art of the Long View, Doubleday (1991); P. M. Senge, The leaders new work: building learning organizations, Sloan Management Review, 7-23 (1990); idem. The Fifth Discipline, the Art \& Practice of the Learning Organization, Doubleday. New York (1990).

(4) J. B. Quinn, Strategic change; logical incrementalism, S/oan Management Review, 7-21 (1978); idem, 55-58 (1989)

(5) According to Keynes: 'Practical men, who believe themselves to be quite exempt from any intellectual influences, are usually the slaves of some defunct economist. 